Article

\title{
Music to Face the Lockdown: An Analysis of Covid-19 Music Narratives on Individual and Social Well-Being
}

\author{
Priscila Alvarez-Cueva \\ Communication Department, Pompeu Fabra University, Spain; priscila.alvarez@upf.edu
}

Submitted: 20 September 2021 | Accepted: 23 November 2021 | Published: 20 April 2022

\begin{abstract}
When the world seemed to collapse due to the Covid-19 pandemic in 2020, music was employed to promote positivity and strength among citizens and communities, especially during worldwide lockdowns. Because the general context of the pandemic was saturated with anxiety, uncertainty, and fear, music -in all its forms of production-became an ideal resource for entertainment and accompaniment, and helped people face the challenges associated with the crisis. Following a qualitative content analysis, this study deeply examines 13 examples of music production published by the United Nations during the Covid-19 crisis, highlighting the narrative elements and how they relate to individual and social well-being. In so doing, the study identifies eight main categories among both lyrics and performances in the music examples. These are: (a) desires, (b) emotions, (c) people, (d) practices, (e) reflections, (f) education/entertainment, (g) allusion to war, and (h) nationalism. The results suggest that music narratives have empowered individuals and social groups by evoking sentiments of solidarity and kindness at both individual and community levels and, in so doing, have contributed to individual and social well-being.
\end{abstract}

\section{Keywords}

content analysis; Covid-19; lockdown; music; well-being

Issue

This article is part of the issue "Promoting Social Inclusive Experiences in Uncertain Times" edited by Ana Belén Cano-Hila (University of Barcelona).

(C) 2022 by the author(s); licensee Cogitatio (Lisbon, Portugal). This article is licensed under a Creative Commons Attribution 4.0 International License (CC BY).

\section{Introduction}

The SDGs of the 2030 agenda interrelate both health and well-being to promote certain measures designed to improve life quality and inclusion of individuals in social activities (United Nations [UN], 2017). From this perspective, it is possible to start connecting how the outbreak of the Covid-19 pandemic and subsequent lockdowns of 2020 not only impacted health systems worldwide but also the well-being of society in general (Gerez et al., 2020; Yang \& Ma, 2020, 2021). As people attempted to adapt to the so-called "new normal," a large number of sentiments were shared in the news, on social networks and, notably in European countries such as Spain and Italy, through public rituals on apartment balconies. The effects of the virus were not limited to the symptoms of disease and illness. The situation also evoked uncertainty and fear (González-Sanguino et al., 2020; Ozamiz-Etxebarria et al., 2020), which made the crisis even deeper and altered peoples' lives in both their individual and social spheres. In this context, professional and amateur musicians started to produce and share music to transmit positivity and strength (Cabedo-Mas et al., 2021; Mas-Herrero et al., 2020), thereby contributing, perhaps unconsciously, to improving personal and social well-being (Martínez-Castilla et al., 2021).

Owing to the cancellation of concerts and events and the mandatory nature of online activities during the quarantines, social media became filled with music videos and songs that related to the lockdown, carried messages of social cohesion and solidarity (Montejano \& Rojas, 2020), and promoted a generally positive view of the future (Zhao et al., 2020). Such sentiments were represented in musicians' initiatives that appeared all over 
the world such as \#SolidaritySession by Chris Martin of Coldplay ("Chris Martin se solidariza," 2020; Perea, 2020), \#LaGiraSeQuedaEnCasa by Juanes and Alejandro Sanz ("Juanes y Alejandro Sanz en concierto," 2020), and "One World: Together at Home," an initiative created by Lady Gaga that assembled numerous musicians and celebrities (Muñoz Pandiella, 2020).

The UN (2020) article Music Does Not Cure a Pandemic, but It Cheers the Soul (author's translation from Spanish) presented examples of music practices that had emerged during the pandemic, evoking the idea that music had been a source of optimism and solidarity throughout the crisis. Within this context, the present study will analyse those music examples promoted by the UN and explore the relationship that music narratives might have for both individual and social well-being. In so doing, the study combines a deductive analysis-following the categories of (a) desires, (b) emotions, (c) people, (d) practices, and (e) reflections (Alvarez-Cueva et al., 2020) - and an inductive analysis that incorporates the principles of grounded theory (Glaser \& Strauss, 1967), thereby allowing new data to emerge from the analysis itself. In other words, the inductive process will identify new categories by the combination of the literature review and the listening/watching process itself.

Section one of this article reviews the current literature and theoretical considerations. Section two provides a description of the data, method employed, and analysis. Section three presents the results. Section four discusses the main findings.

\section{Literature Review and Theoretical Considerations}

\subsection{Music and Well-Being}

In recent years, music has been analysed in terms of its role in life on both the individual and the social level. Audiences use music not only for entertainment (Bennett, 2001) but also as a "resource for the conduct of emotional 'work,' and for heightening or changing energy levels" (Denora, 1999, p. 31). Studies have also shown that music can be incorporated into different forms of therapy to prevent mental illness (Poulos et al., 2019) and to mitigate the symptoms of other illnesses such as dementia (Ho et al., 2019). Music, in all its forms of production, accompanies daily life with a great impact on identification processes (Acord \& Denora, 2008; Hall \& Du Gay, 2003). Acord and Denora (2008) argue that aesthetic objects function as arbiters of social relations, meaning, and action and that they are used to organize the daily existence of both individuals and groups. Therefore, understanding the relationship between music and well-being is particularly relevant during crisis scenarios such as the pandemic. In this sense, music - both lyrics and visual performances-may help organize the so-called new normality while exacerbating emotions to face the crisis. Indeed, several stud- ies have highlighted the role of music in promoting social cohesion and support. Moss (2019), for instance, argues about the spiritual benefits of music therapy and how music helped to transcend difficulties and find meaning in suffering. Similar ideas are present in a study of community choir initiatives, in which the authors argue that music practice reduces loneliness and increases the interest of older adults in community life (Johnson et al., 2020). These works suggest that music engagement and practice may lead to subjective and social well-being.

Lindblad and de Boise (2020) argue that music creation and/or practice fills psychological, social, and emotional needs among older men. Based on a set of semistructured interviews with Swedish men aged 66-76, their study draws a contrast between "being" with music and doing/practising musical activities. In the context of crisis that concerns the present study, these findings connect with both practices of listening and producing music during the pandemic. In this sense, the work of Kwok (2019) suggests that students who experimented with music therapy from a positive psychology perspective had significant increases in emotional competence, hope, individual happiness, and a significant decrease in anxiety. It is well known that music therapy requires professional assistance, but Kwok's (2019) study suggests that we should think about music as a broader resource for emotional competencies. In this regard, it is important to recognise that the emotion that was transversal during the pandemic was anxiety.

As Keng et al. (2021) suggest, music therapy stress reduction (MTSR) may have a unique impact on negative emotions. Enge and Stige (2021), for their part, argued that music therapy nurtures a child's capacity to regulate emotions and engage in social activities. These works do not suggest that music itself is a form of medicine, but rather-considering context, environmental conditions, individual and social values and beliefs, social inequalities, and social dynamics - it influences subjective and collective well-being (Daykin et al., 2017).

Fanian et al.'s (2015) study of Canadian indigenous youth analyses creative arts workshops that explored community issues and possible solutions by using the arts. They report that indigenous youth gained confidence and new skills. Furthermore, Calderón-Garrido et al. (2018) used a questionnaire to explore the experiences and opinions of 462 people of different ages, sex, educational levels, and artistic backgrounds. They found that a large majority believed that art (particularly music) improved their state of mind. Therefore, it is possible to see that arts in general, and engagement and participation in music practices in particular, have the potential to build resilience and stimulate social dialogue (Calderón-Garrido et al., 2018; Fanian et al., 2015).

Furthermore, emotional intelligence-which corresponds to both intrapersonal and interpersonal intelligence-is also related to listening to and making music. Oriola and Gustems (2015) argue that music education contributes to developing and improving 
emotional competencies. In so doing, the authors addressed five different forms of emotional intelligence within musical education: (a) emotional consciousness, (b) emotional regulation, (c) emotional autonomy, (d) social nature capacities, and (e) capacities related to wellbeing and life. Nevertheless, these different forms of emotional intelligence can also be discussed in other contexts, such as the pandemic, where emotional intelligence played a key role in relation to well-being.

Within this context, this article argues that at the same time the world was facing the challenges associated with Covid-19, music indeed functioned as a sort of escape route, not only for amateur or professional musicians but also to people, in general, while making sense of the crisis. In so doing, music helped strengthen both individual and social spheres that, in turn, are the basis for well-being. Although the notion of well-being has been analysed from different perspectives (Fletcher, 2016; Stone \& Mackie, 2013), this study understands well-being as "the series of momentary affective states that occur through time" (Stone \& Mackie, 2013, p. 29) that may impact in both individual and social spheres.

\subsection{Music, an Antidote to the Effects of the Coronavirus}

During the pandemic, music was used as a therapeutic vehicle to reduce discomfort while strengthening emotional support (Partida Valdivia, 2020). In this sense, music achieved two main actions: it alerted and informed about prevention strategies (Mulemi, 2021) and it mitigated the impacts of the administrative measures to contain the virus spread, which included social distancing and lockdowns (Beam \& Kim, 2020; Tull et al., 2020). Beam and Kim (2020) draw attention to both young and old adults who faced problems due to isolation measures and loneliness. Likewise, Tull et al. (2020) analysed the psychological consequences of Covid-19 prevention measures (such as stay-at-home orders) among women and men around 40 years old, highlighting that prevention strategies were associated with greater levels of health anxiety, financial worry, and loneliness. These studies suggest that social connection is crucial to mitigate the negative consequences of the pandemic, a scenario that also extends to healthcare personnel and people on the front line (Giordano et al., 2020).

A previous study (Alvarez-Cueva et al., 2020) drew the remarkable benefits on people's well-being of making, sharing, and seeing music, classifying them in four main areas: (a) physical health, (b) self-confidence and optimism, (c) solidarity and social support, and (d) the development of skills and knowledge related to a particular situation. Other studies have analysed the role that music played during the pandemic and the lockdown periods in different places around the world. Ferreri et al. (2021) conducted a study in the USA, Spain, and Italy and argued that people spent more time than usual on activities related to music during the pandemic, pointing out that music selection depended on individual sensibility, emotional regulation strategies, regulation of stress, and cheering themselves up. A study developed in France, Germany, India, Italy, the USA, and the UK demonstrates how important real-time musical responses are when facing societal crises (Fink et al., 2021). Martínez-Castilla et al. (2021) argue that musical activity was carried out to support emotional well-being during lockdowns in Spain, where more vulnerable people found greater benefit from musical behaviours. The study conducted by MacDonald et al. (2021) analysed improvisation of musical practices with artists in Glasgow. From the interviews, key topics have been highlighted: "enhanced mood, reduced feelings of isolation, and sustained and developed community" (MacDonald et al., 2021, p. 1). Likewise, Martín et al. (2021) point out that, during the lockdown in Spain, music emerged as the form of artistic expression most used to face situations of loneliness, to maintain relationships with others despite the social distancing measures, and to minimize possible psychological states and negative emotional factors derived from, among other causes, nostalgia and anguish, which have been broadly associated with crises (Gibbs \& Egermann, 2021).

Ozamiz-Etxebarria et al. (2020) argue that stress derived from the lockdowns in Spain mainly affected young people including those with some type of chronic illness. Similarly, González-Sanguino et al. (2020) explore the effects on 18-25-year-olds and 26-60-year-olds whose emotional states during lockdown were also associated with anxiety and depression. In this scenario, Covid-19 and the different measures implemented over the last year and a half have had an enormous impact on society.

The virtual stages on which musical activity was developed during lockdown (Montejano \& Rojas, 2020) have been key in helping people face the changing reality brought about by the pandemic (Calvo \& Bejarano, 2020; Daykin et al., 2018). For this reason, it is not surprising that various studies highlight the effects of music on the regulation of mood and the promotion of social cohesion in times of adversity such as the pandemic (Chiu, 2020). For instance, Cabedo-Mas et al. (2021) suggest that during periods of confinement, there was an increase in the time used for activities related to music and that music was seen as a tool to escape from reality and improve one's mood. This idea is consistent with the work of Ferreri et al. (2021), who argue that the activities that people carried out while listening to happy music and discovering new songs are linked to the regulation of healthy emotions (Fink et al., 2021; Hansen, 2021). Music was of such relevance during the pandemic that Hansen et al. (2021) propose the term "coronamusic" to emphasize the role it had among individuals and social groups. Indeed, all these studies point out the relevance of music in helping people face the crisis (see also Zhao et al., 2020). Therefore, it is possible to understand music as Rimé (2009) suggests, this is, as a tool that stimulates 
social ties, collaborates with mental health, and impacts well-being on both personal and social levels.

This article builds on the work of scholars who have argued that music helps regulate one's emotional state (Mas-Herrero et al., 2020) to the point of being the most efficient activity and resource for the promotion of well-being (Granot et al., 2021), by unravelling music narratives that emerged during the pandemic and critically analysing their relationship with both individual and social well-being.

\section{Data and Methods}

\subsection{Qualitative Data Approach and Method}

The sample of the present study has been established on the music list published by the UN (2020), where a total of 13 songs and videos were presented, divided into four sections: (a) viral music from the initial period of Covid-19, (b) online festivals, (c) old songs as anthems, and (d) UN professional collaborations. One characteristic of the music list is its connection to Hispanic identity. Most of the examples are in the Spanish language and come from different Spanish-speaking countries. The sample includes a broad range of Spanish singers, artists, and campaigns that were aimed at helping to combat the health crisis from different positions: to favour children, to help first-line personnel, etc. Although the sample covers only a small proportion of what people were listening to and sharing during the pandemic, it represents a remarkable variety of productions that have connected people.

The first section of the music list comprises three examples: Horacio Rodrigues' song, an amateur Argentinian production with more than 65,000 YouTube views; the Catalan trio Stay Homas, which started producing music during the lockdown in Spain; and Sheila Blanco, a professional singer and journalist who uses YouTube to make classic composers accessible to a broader audience. The first section, therefore, includes an amateur musician, a small group that became famous during the pandemic, and a professional education initiative. The second section of the music list includes different examples, ranging from a Cuban artistic initiative to the \#YoMeQuedoEnCasaFestival in Spain, where more than 160 artists collaborated. The third section of the list explains how some old and classic songs were revived due to the Covid-19 crisis and helped unify society. To exemplify this, the list includes the songs Contigo Perú, performed by members of the National Choir of Peru and the National Children's Choir, Como la Cigarra, a collaboration of more than 30 Argentinian artists, and Resistiré México, which resonates in different countries since versions of the original song (by Dúo Dinámico) have been made by Spanish, Ecuadorian, Colombian, and Chilenian artists, among others. Finally, the fourth section of the list combines music initiatives that aimed to gather contributions for different social campaigns related to the Covid-19 crisis. The list includes Pa'lante by Salomon Beda-part of the campaign \#VolveránLosAbrazos, that assembled artists from countries including Venezuela, Puerto Rico, Chile, Perú, and the USA. The list also includes Pablo Alborán with the song Cuando Estés Aquí, who contributed to a UNICEF's campaign, and the worldwide initiative led by Lady Gaga "One World Together at Home," which raised more than 125 million dollars and included Hispanic artists such as Juanes, Luis Fonsi, and Maluma. In sum, the sample contains a variety of examples that share characteristics with other similar music productions that are not considered in the present work. The sample, therefore, provides the means of highlighting elements that resonate with other examples of music that emerged or became popular during the Covid-19 crisis.

In this study, both music lyrics and videos are considered. The analysis is carried out following a deductive method (Alvarez-Cueva et al., 2020) based on five categories of music creation in times of confinement-i.e., (a) desires, (b) emotions, (c) people, (d) practices, and (e) reflections-and an inductive method supported on the fundamentals of grounded theory (Glaser \& Strauss, 1967). This entails an iterative process of data collection from the units of analysis - both lyrics and videos-and the process of qualitative analysis within the theoretical framework. In so doing, the study develops a qualitative content analysis (Krippendorff, 2004) of lyrics and music videos that allows the analysis to move randomly through the different elements of the music narratives to include as many as possible. This refers, for instance, to artists' speeches (when necessary, e.g., during online festivals). All the data was organized and categorized using Nvivo12 software.

\subsection{Conducting the Qualitative Analysis}

The first step consisted of codifying the thirteen cases and revising each of their videos and lyrics. The units of analysis were separated by differentiation regarding lyrics and videos-with " " if available and " $N$ " if it was not accessible. The study dismissed lyrics and/or videos if the example was unsuitable for the analysis. Three of the units of the analysis presented a sort of limitation in this sense. To still include as many units of analysis as possible, the study determined the following: for the first case (C_004), the analysis would only include the video of the song; for the second case (C_006), the analysis would focus particularly on the artist's speech during her participation in the online festival; and, finally, the study eliminates the last case (C_008) because it was the only one transmitted in segments via Twitter and was neither an original song nor had a significant number of plays. The units of analysis were established as elaborated upon in Table 1.

In addition, transcription of lyrics was done prior to analysis using the software. For the codification, both deductive and inductive processes were developed. 
Table 1. Total sample and the final units of analysis established.

\begin{tabular}{llcc}
\hline Code & Title and artist & Lyrics & Video \\
\hline C_001 & Me Quedo en casa Porque te Quiero (Horacio Rodriguez) & Y & Y \\
C_002 & Ya No Puedo Más (Stay Homas, Sílvia Pérez Cruz) & Y & Y \\
C_003 & El Moderno Debussy (Sheila Blanco) & Y & Y \\
C_004 & Sheila Blanco and Federico Lechner performing at IFEMA & Y & Y \\
C_005 & "Tunturuntu Pa' Tu Casa Sábado: 21 de Marzo de 2020” & Y & Y \\
C_006 & Live concert \#YoMeQuedoEnCasaFestival (Sofía Ellar) & Y & Y \\
C_007 & Argentina sings La Cigarra by María Elena Walsh (various artists) & Y & Y \\
C_009 & Contigo Perú (National Choir of Peru and the National Children's Choir) & Y & Y \\
C_010 & Resistiré México (various artists) & Y \\
C_011 & Pa'lante (Salomón Beda feat. 16 Latinoamerican artists) & Y \\
C_012 & Cuando Estés Aquí (Pablo Alborán) & Y \\
C_013 & Smile (Lady Gaga at the “One World: Together at Home” festival) & Y \\
\hline
\end{tabular}

Nodes in Nvivo12 were created for the deductive categories mentioned above. Sub-nodes were created for positive, negative, uncertain, and longing emotions (Alvarez-Cueva et al., 2020). This deductive strategy allowed the data to be detected and organized following the narratives and elements of lockdown music production, mainly because not all the songs were created for the pandemic but were rather recovered because they resonated with it. The inductive strategy of grounded theory (Glaser \& Strauss, 1967) allowed the codification and analysis to interrelate the literature review with the most important elements of each unit of analysis and, in so doing, three additional nodes (categories) were identified: education/entertainment, allusion to war, and nationalism. Before presenting the results, it is pertinent to mention that the analysis determined most of the videos as homemade because both amateur and professional musicians were singing mainly from their homes. The exceptions are examples C_012, which features a professionally produced animation that accompanies the artist, and C_004, in which the artists are singing outside a hospital in Madrid, Spain.

\section{Results}

A total of eight transversal elements are highlighted from the analysis: (a) desires, (b) emotions, (c) people, (d) practices, (e) reflections, (f) education/ entertainment, (g) allusion to war, and (h) nationalism. The results are presented in two sections: The first section will focus on the deductive results, while the second will present the inductive data. In both sections, results will be accompanied by some video screenshots to illustrate the findings. Nevertheless, in the discussion, the article presents how all the elements are interconnected with one another and with questions of well-being at an individual and social level.

\subsection{Music and Lockdown: An Opportunity to Rethink the Battle to Win}

The five deductive categories were identified, although four of them were more remarkable among the sample, these are reflections, emotions, practices, and desires.

Reflections are mainly related to two ideas: On one hand, a sort of unity-meaning the strengthening of social ties to face the virus and the crisis; on the other hand, reflections on life while being separated from others. Most of the references in this regard link with the necessity of helping individually-a sort of "do your part" message. Reflections, in general, allow us to understand music as part of a process of rethinking life and seeing lockdowns as opportunities to learn and resist. This idea, precisely, links with Moss' (2019) argument on the benefits of finding meaning during hard times. During the Covid-19 crisis, and particularly when lockdowns started being imposed, the difficulties that music helped people go through encouraged the individual to embrace collective resistance and, in so doing, alluded to "war" and "battle." Both of these scenarios would need to follow a strategy of fighting as a team and watching each other's backs to finally be able to see life value and take back good moments with the loved ones. According to this category, the future would be a "new beginning" in which hugs and smiles would return. In one example (C_013), Lady Gaga illustrates this idea when she sings "you'll see that life is still worthwhile if you just smile" (see Figure 1).

The second most important category is emotions, which relates to the different feelings both amateur and professional artists shared through their music during the crisis and lockdowns. To examine each of these emotions thoroughly, the study subdivides them into longing, positive, negative, and uncertain emotions.

Longing emotions were common to most of the songs among the sample, related to missing loved ones as crucial in this regard. In dialogue with a previous 


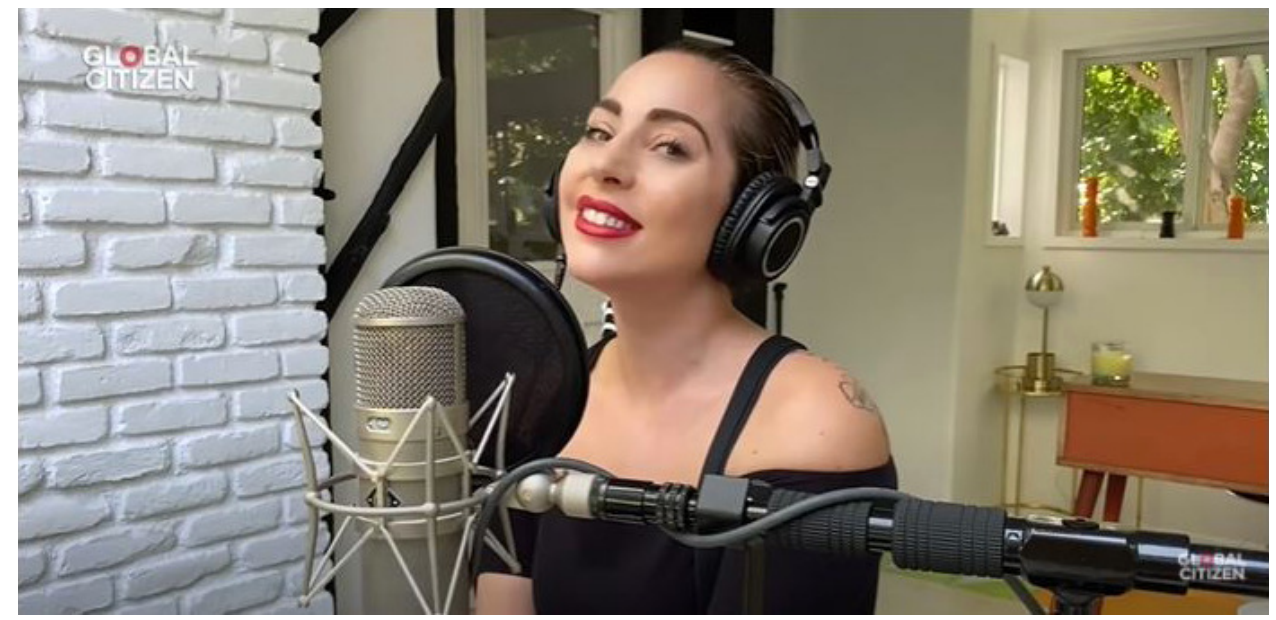

Figure 1. Lady Gaga performs Smile at “One World: Together At Home.” Source: Global Citizen (2020).

study (Alvarez-Cueva et al., 2020), longing emotions link with the desire and need to return to a pre-pandemic lifestyle. Through these emotions, it is possible to see how Covid-19 shifted known life worldwide, resulting in the emergence of romanticized references to what people used to do before the pandemic - a state that is both valuable and achievable with patience and faith.

Positive emotions are also highlighted among the sample. As mentioned before, most of the categories are interrelated to one another and positive emotions were fundamental to all the narratives analysed, either because the lyrics made direct references to "smile," "hug," "resurge," or because the videoclips suggested positivity through its presentational style, especially when the screen was split into many spaces where different people were singing together while smiling at the camera. The online interaction due to social distancing measures not only contributed to trying to hold social networks but, particularly in the case of music, permitted the reinforcement of previous ties through the energy that is conveyed in music. As argued in relation to com- munity choir (Johnson et al., 2020), the examples of positive emotions shared by multiple singers might help reduce sentiments of loneliness and increase the interest in helping and supporting each other (see Figures 2 and 3).

Positive emotions are consistent even when a melancholier melody is used, as demonstrated in C_ 012 by the metaphorical reference portrayed by free-flying birds at the end of the clip (Figure 4). This in turn links back to the longing emotions explained above. In general, positive emotions nurtured individual and social bonds during the crisis and, in so doing, stimulated social ties and had a positive impact on well-being (Rimé, 2009).

Negative emotions were also combined with longing emotions, transforming feelings of missing loved ones, sadness, and suffering into a sort of motivation to keep waiting and hoping for a better tomorrow. "Learning from suffering" (Moss, 2019) takes place so that the individual (as well as others) understands and values social bonds, takes care of missing ones and, as a consequence, "does it right" when the moment comes. This

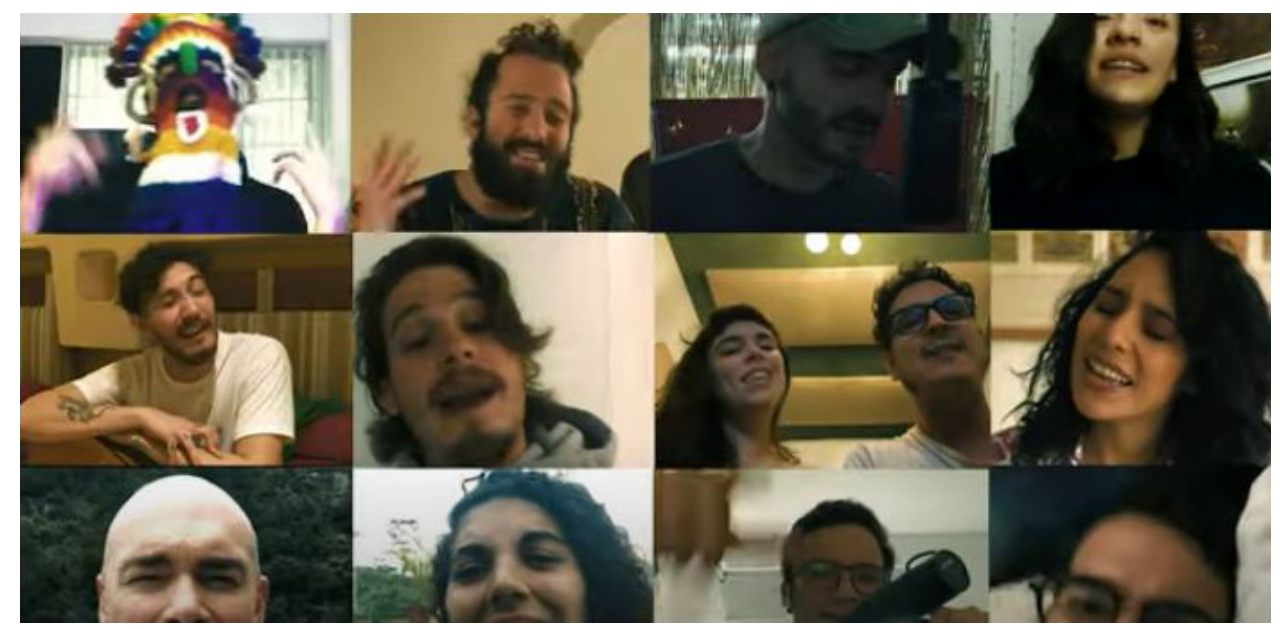

Figure 2. Screenshot from the official music video of Pa'lante, by Salomón Beda feat. 16 artistas Latinoamericanos. Source: Beda (2020). 


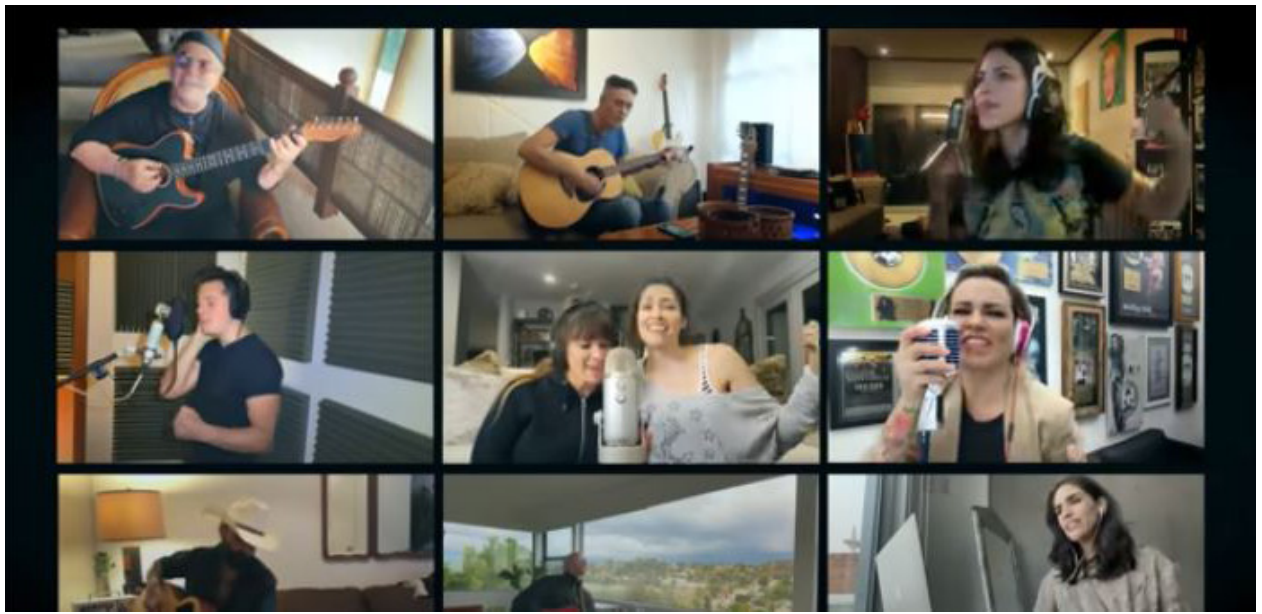

Figure 3. Screenshot from the official music video of Resistiré México. Source: Warner Music México (2020).

social dialogue (Calderón-Garrido et al., 2018), even when considering negative emotions, promotes the idea that moods can still be improved in uncertain times.

Applying the same principles of music as a resource for building resiliency and relationships (Fanian et al., 2015), we can see that uncertain emotions are also highlighted among the narratives analysed. One of the sample songs (C_011), translated here from the original Spanish, proves a remarkable example (from Spanish):

As much as the vertigo of not knowing exactly what can happen can have you cornered against the wall / Now that she comes, she will be the one who left, everything that she was now is not, she will continue to be so later / It has been that way since there once was.

Practices were the third most important category in the sample. These narratives were mainly used as reminders of the official measures (C_001, C_005, C_006, C_008, C_013) and made frequent mentions of social distancing and stay-at-home as an obligation and responsibility for yourself and others during the crisis (see Figure 5). When thinking about the relationship between emotional intelligence and music (Oriola \& Gustems, 2015), it is possible to associate the practices described in the narratives with consciousness awakening as well as with emotional regulation and autonomy during the crisis. This means realising that part of the solution (at least) relied on each person following the recommended prevention measures. Furthermore, the capacities related to well-being and life might also be stimulated through the constant reminder of environmental conditions and individual and social implications and dynamics (Daykin et al., 2017; Mulemi, 2021).

The fourth category is desires, which is linked with spirituality (C_001) when evoking, for example, God to save Argentina and all countries, from Latin America to China. Desires also evoked memories of hugs, of being together, of smiles (C_013), or simply of being able to continue doing the activities we enjoyed the most (C_002). In so doing, they reinforce the idea of keeping moving forward (C_011). In this category, most of the previous elements convey again stimulation of social

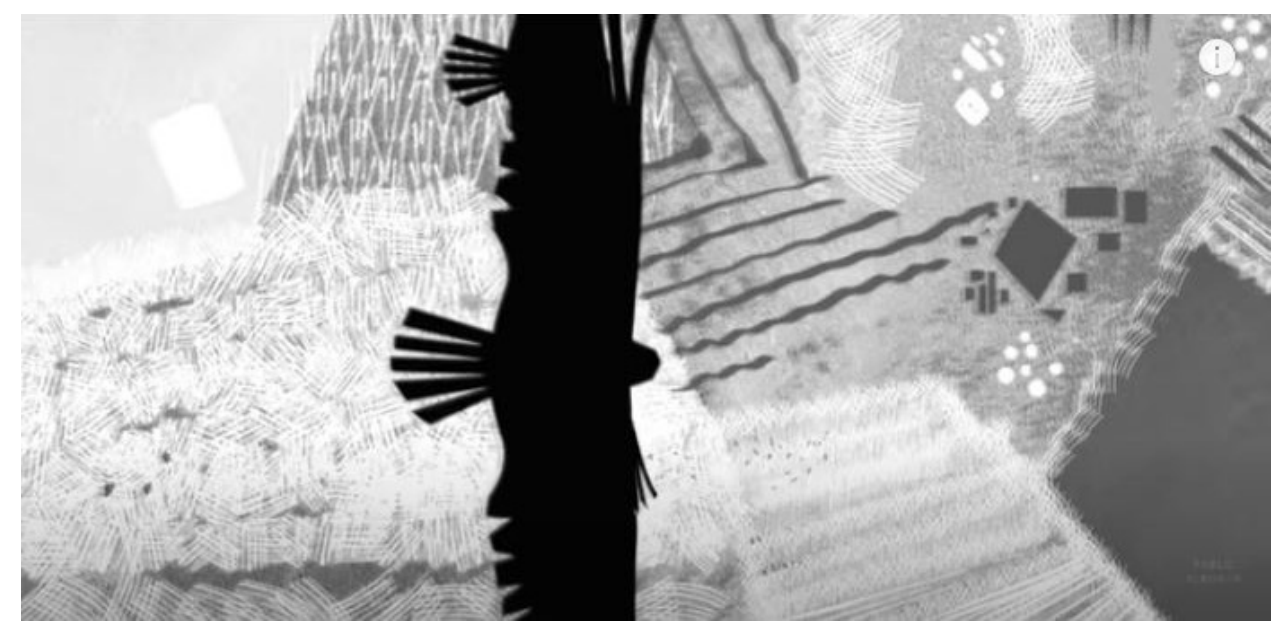

Figure 4. Screenshot from the official music video of Cuando Estés Aquí. Source: Alborán (2020). 


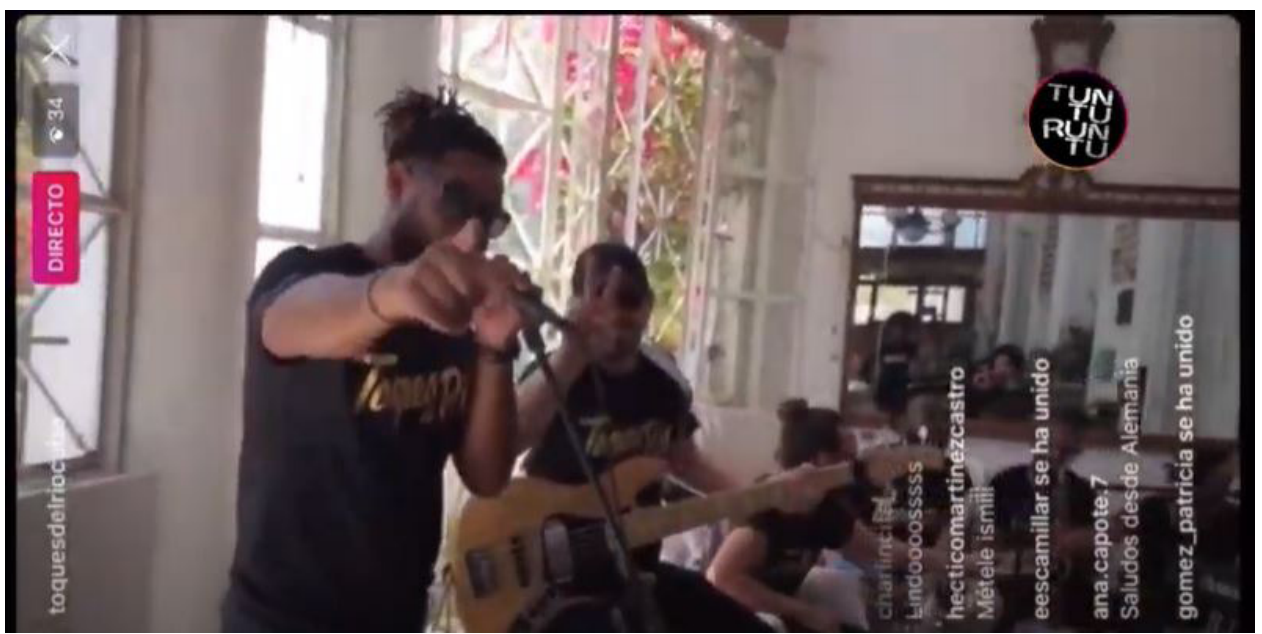

Figure 5. Screenshot from the project Tunturuntu Pa' tu Casa Sábado: 21 de Marzo de 2020. Source: Tunturuntu Cuba (2020).

bonds (Rimé, 2009) that go beyond geographical borders. Desires are particularly relevant for the study because music creation implies an intentional message in their lyrics. Therefore, when transmitted, desires connect with one's individual and social sphere through a reality that arguably became very similar around the globe. If the pandemic demonstrated anything at its inception stage, it is that humanity shares much more similarities, such as vulnerability and anxiety, than differences. An interesting example of new and global lifestyle practicesthe result of adapting our means of communication-is present in C_007, an intervention of various artists, performing on what seems to be a WhatsApp group entitled \#AngentinaCanta (see Figure 6).

\subsection{Linking the Personal and the Collective: Weaving Emotions to Act and Be Safe}

Three final categories were inductively found among the sample: education/entertainment, allusions to war, and nationalism.
The education/entertainment category is represented in C_003. This is remarkable, since the Covid-19 crisis demanded, among other factors, working from home and online activities that ruled people's daily lives. In this sense, education also faced a significant challenge (Cano-Hila \& Argemí-Baldich, 2021). By mirroring life, music contributed to combining emotional competencies (Kwok, 2019) and the context of the pandemic (Daykin et al., 2017). The category of education/entertainment is combined because music affords a more creative form of self-expression at the same time it opens new ways for teaching and learning (DeNora, 2003). These activities can improve the development of emotional consciousness, regulation, and autonomy, as well as comprehension of the social situation, selfawareness, and well-being (Oriola \& Gustems, 2015).

The second category is allusions to war. Some lyrics evoked memories of war and resistance, presumably because of the uncertainty and fear caused by the pandemic. As mentioned before, this narrative links back to Moss' (2019) reflections of learning from difficulties

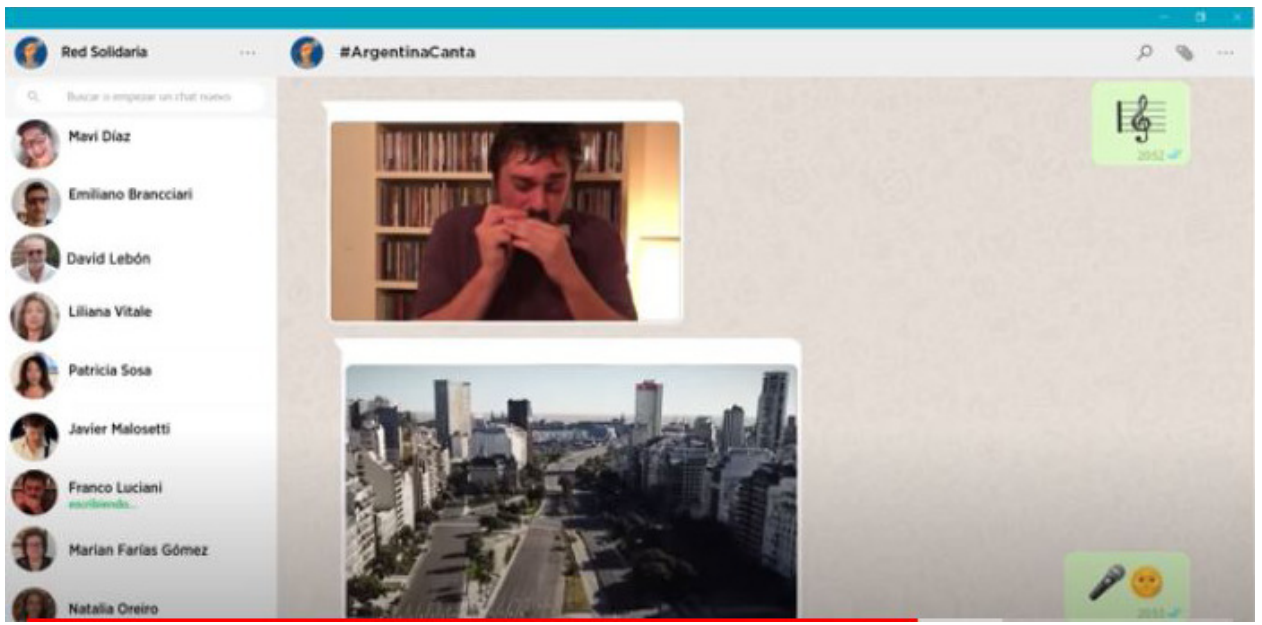

Figure 6. Argentina sings La Cigarra by María Elena Walsh. Source: Televisión Pública (2020). 
and finding meaning in the suffering they often provoke. Allusions to war, however, are interrelated also to the need to influence collective well-being (Daykin et al., 2017) by appealing to individual responsibility and emotional autonomy (Oriola \& Gustems, 20115). War scenarios are charged visual imaginaries that are capable of influencing memories of catastrophe that many people would prefer to avoid. However, these narratives can enable a more valuable sense of autonomy and heroism specific to this crisis context. Several songs (C_001, C_007, C_010) employed allusions to war to unify society against a common enemy: the virus. Therefore, both strategies to prevent contagion and encouragement to "fight" the battle were important. In this context, C_010 repeatedly used the same narrative in different countries and different languages. Resistance (resistiré) became a sort of anthem, especially during lockdown-indeed, it was included in the sub-headline of the UN article previously alluded to. One song (C_004) also portrayed a sort of tribute to healthcare personnel and people on the front line in a hospital in Madrid, Spain. This action combined feelings of gratitude and thoughts of strength to keep battling adversity (see Figure 7).

Building on the idea of an anthem to unify society, the last category explored in this article is nationalism. This narrative reinforced the message of unity and strength to face the crisis with a more profound impact on one's individual and social spheres (Daykin et al., 2017). If allusions to war might provoke responsibility in such a way that the individual felt responsible for the situation, the addition of nationalism goes even further, evoking the sentiment that "patriotism in battle" is the key to success. This "military squad" allusion is identifiable in one example that includes images of men and women in uniform (C_009; see Figure 8). In this sense, feelings derived from nationalism narratives might also produce an increased cohesion of existent social ties and even build new ones (Calderón-Garrido et al., 2018; Fanian et al., 2015). Feelings of patriotism encourage people to take their part in the crisis scenario and be responsible for helping themselves and others. In so doing, these emotions also produce feelings of satisfaction and pride that serve as a basis for promoting individual and social well-being. We recall the lyrics, here translated from the original Spanish, to Contigo Perú:

When I wake up and I see that I continue to live with you, Peru, I thank heaven for giving me life with you, Peru....We are all with you, Peru....We are your children, and we will unite, and thus we will triumph with you, Peru.

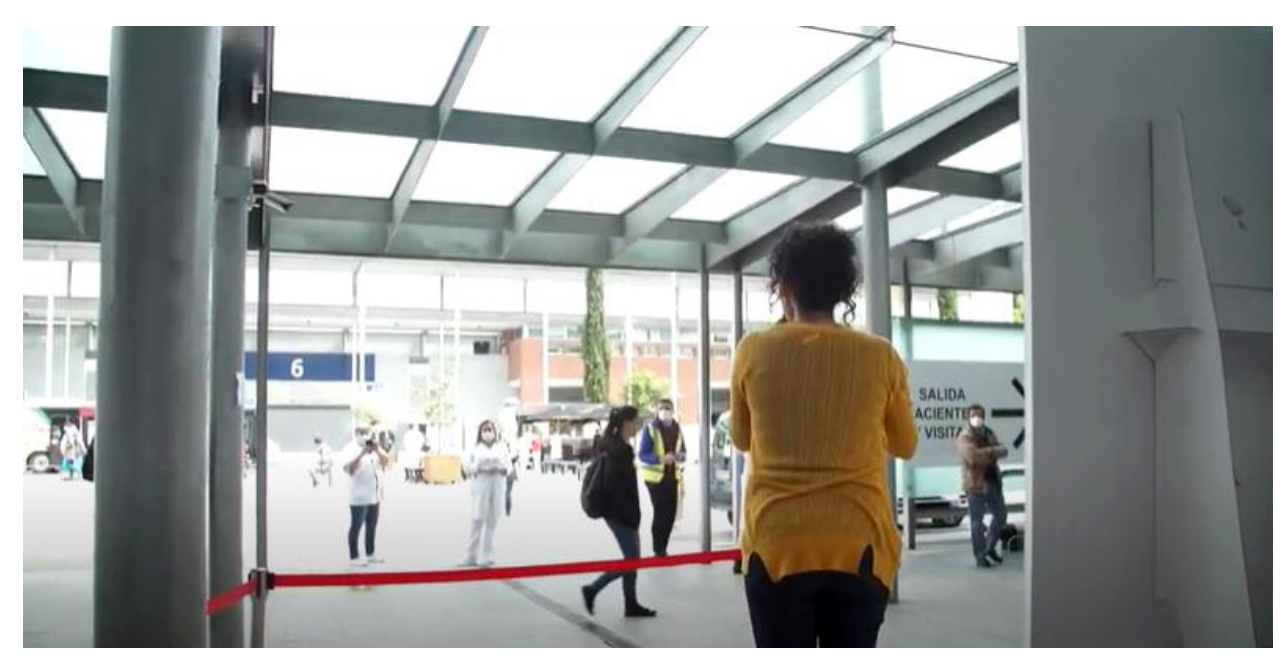

Figure 7. Sheila Blanco and Federico Lechner performing at IFEMA. Source: IFEMA (2020).
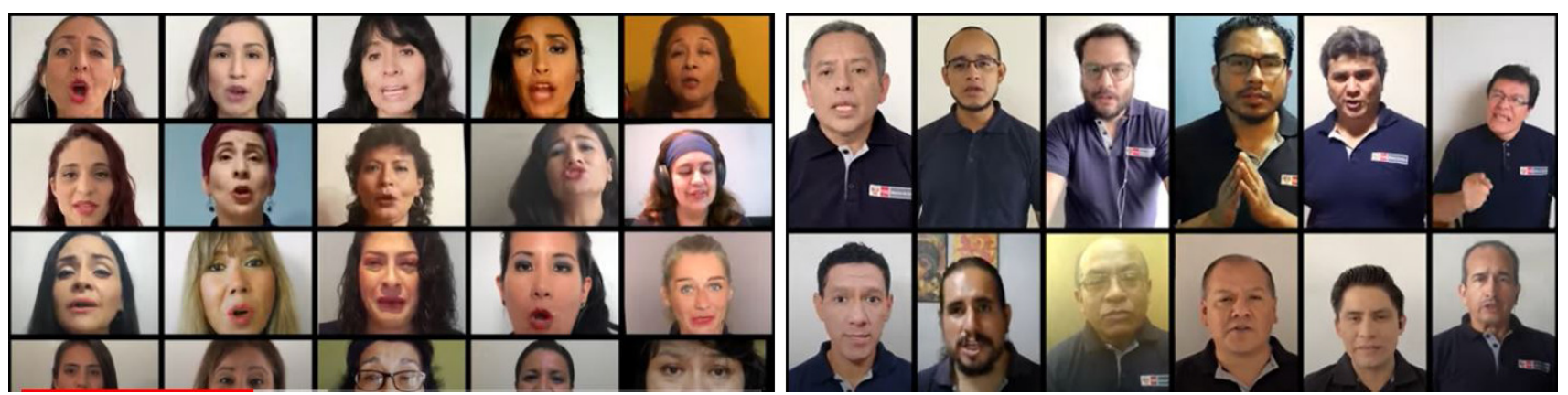

Figure 8. Screenshots of Contigo Perú being performed by the National Choir of Peru and the National Children's Choir. Source: Ministerio de Cultura de Perú (2020). 


\section{Discussion}

The present study identifies eight elements present in the narratives of the so-called "coronamusic" (Hansen et al., 2021) identified by the UN (2020). These elements are (a) desires, (b) emotions, (c) people, (d) practices, (e) reflections, (f) education/entertainment, (g) allusions to war, and (h) nationalism. Combined, these elements played a crucial role in transmitting sentiments of solidarity and responsibility during the crisis. The study argues that music enables a social dialogue (Fanian et al., 2015) that improve emotional competencies (Kwok, 2019), appealing in particular to the individual (Oriola \& Gustems, 2015) and, in so doing, resonating with the collective (Daykin et al., 2017). Therefore, ideas of "unity" were crucial not only to maintain faith in the future but also to encourage people to think of themselves and others and help them face the situation. Most of the songs analysed in this article repeat messages of seeing the crisis and lockdowns as an opportunity to learn and to resist (Moss, 2019), to dream of new beginnings. In a context that is constantly being compared to scenarios of war and battle, feeling the absence of loved ones (the very emotion it entails) demarcated a space in which individuals may have felt responsible for themselves and others, but where they also promoted attitudes and routines that helped them cope with the crisis.

This study argues that music relates to individual and social well-being. Music helped people navigate the situation by empowering them in their individual and collective spheres, while they were learning how to prevent contagion, appealing to emotions that create a positive view of the crisis. This lesson might help us grow and build a better future. In sum, the music of both amateur and professional artists produced in the pandemic evoked solidarity and kindness, thus helping people remain calm and providing them with the faith they needed to face the crisis.

Future studies may include audiences' perspectives to deeply problematize the relationship between music and one's individual and social spheres, particularly in scenarios of crisis.

\section{Acknowledgments}

The author wants to thank the editor of this thematic issue and reviewers for their helpful comments in improving the present article. Furthermore, special thanks are due to Eduard Ballesté and Rafel Argemí for their encouragement and feedback during the writing of the article.

\section{Conflict of Interests}

The author declares no conflict of interests.

\section{References}

Acord, S. K., \& Denora, T. (2008). Culture and the arts: From art worlds to arts-in-action. Annals of the American Academy of Political and Social Science, 619(1), 223-237. https://doi.org/10.1177/ 0002716208318634

Alborán, P. (2020, April 13). Pablo Alborán: Cuando estés aquí [Pablo Alborán: When you are here] [Video]. https://www.youtube.com/watch?v=b8qTORBwGPo

Alvarez-Cueva, P., Masanet, M.-J., \& Cano-Hila, A. B. (2020). Las narraciones de la cuarentena durante la crisis de la Covid-19 a través de la música: Emociones y actividades compartidas por Stay Homas [Narratives from the quarantine during the Covid-19 crisis through music: Shared emotions and activities by Stay Homas]. Hipertext.net, 2020(21), 67-77. https:// doi.org/10.31009/hipertext.net.2020.i21.06

Beam, C. R., \& Kim, A. J. (2020). Psychological sequelae of social isolation and loneliness might be a larger problem in young adults than older adults. Psychological Trauma: Theory, Research, Practice and Policy, 12(S1), 58-60. https://doi.org/10.1037/tra0000774

Beda, S. (2020, April 11). Salomón Beda: Pa'lante feat. 16 artistas Latinoamericanos [Salomón Beda: Pa'lante feat. 16 Latin artists] [Video]. https://www.youtube. com/watch?v=Y5jwkDM-AQc

Bennett, A. (2001). Cultures of popular music. Marston Book Services.

Cabedo-Mas, A., Arriaga-Sanz, C., \& Moliner-Miravet, L. (2021). Uses and perceptions of music in times of Covid-19: A Spanish population survey. Frontiers in Psychology, 11. https://doi.org/10.3389/fpsyg.2020. 606180

Calderón-Garrido, D., Martín-Piñol, C., Gustems-Carnicer, J., \& Portela-Fontán, A. (2018). La influencia de las artes como motor de bienestar: Un estudio exploratorio [The influence of the arts as drivers of well-being: An exploratory study]. Arte, Individuo y Sociedad, 30(1), 77-93. https://doi.org/10.5209/ARIS.56350

Calvo, K., \& Bejarano, E. (2020). Music, solidarities and balconies in Spain. Interface: A Journal for and About Social Movements, 11(2), 1-7. http://dx.doi.org/ 10.17502/m.rcs.v8i1.333

Cano-Hila, A. B., \& Argemí-Baldich, R. (2021). Early childhood and lockdown: The challenge of building a virtual mutual support network between children, families and school for sustainable education and increasing their well-being. Sustainability, 13(7). https://doi. org/10.3390/SU13073654

Chiu, R. (2020). Functions of music making under lockdown: A trans-historical perspective across two pandemics. Frontiers in Psychology, 11. https://doi.org/ 10.3389/fpsyg.2020.616499

Chris Martin se solidariza y da ánimos para sobrellevar la cuarentena [Chris Martin shows solidarity and offers encouragement for coping with quarantine]. (2020, March 16). El Universal. https://www. eluniversal.com.mx/espectaculos/musica/chrismartin-se-solidariza-y-da-animos-para-sobrellevarla-cuarentena

Daykin, N., De Viggiani, N., Moriarty, Y., \& Pilkington, 
P. (2017). Music-making for health and wellbeing in youth justice settings: Mediated affordances and the impact of context and social relations. Sociology of Health and IIIness, 30(6), 941-958. https://doi.org/ 10.1111/1467-9566.12549

Daykin, N., Mansfield, L., Meads, C., Julier, G., Tomlinson, A., Payne, A., Grigsby Duffy, L., Lane, J., D'Innocenzo, G., Burnett, A., Kay, T., Dolan, P., Testoni, S., Victor, C., \& Victor, C. (2018). What works for wellbeing? A systematic review of wellbeing outcomes for music and singing in adults. Perspectives in Public Health, 138(1), 39-46. https://doi.org/10.1177/ 1757913917740391

Denora, T. (1999). Music as a technology of the self. Poetics, 27(1), 31-56. https://doi.org/10.1016/S0304422X(99)00017-0

DeNora, T. (2003). Music sociology: Getting the music into the action. British Journal of Music Education, 20(2), 165-177. https://doi.org/10.1017/S0265 051703005369

Enge, K. E. A., \& Stige, B. (2021). Musical pathways to the peer community: A collective case study of refugee children's use of music therapy. Nordic Journal of Music Therapy. Advance online publication. https:// doi.org/10.1080/08098131.2021.1891130

Fanian, S., Young, S. K., Mantla, M., Daniels, A., \& Chatwood, S. (2015). Evaluation of the Kóts'iihtła ("we light the fire"). International Journal of Circumpolar Health, 74(1). https://doi.org/10.3402/ijch.v74. 27672

Ferreri, L., Singer, N., McPhee, M., Ripollés, P., Zatorre, R. J., \& Mas-Herrero, E. (2021). Engagement in musicrelated activities during the Covid-19 pandemic as a mirror of individual differences in musical reward and coping strategies. Frontiers in Psychology, 12. https:// doi.org/10.3389/fpsyg.2021.673772

Fink, L. K., Warrenburg, L. A., Howlin, C., Randall, W. M., Hansen, N. C., \& Wald-Fuhrmann, M. (2021). Viral tunes: Changes in musical behaviours and interest in coronamusic predict socio-emotional coping during Covid-19 lockdown. Humanities and Social Sciences Communications, 8(1), 1-11. https://doi.org/ 10.1057/s41599-021-00858-y

Fletcher, G. (Ed.). (2016). The Routledge handbook of philosophy of well-being. Routledge. https://doi.org/ 10.4324/9781351048521

Gerez, A., Mac Millan, A., Estupiñá, G. ,Sistac, H., Albós, J., \& Martí, N. (2020). El control en los tiempos del coronavirus [Control in times of coronavirus]. Perifèria: Revista de recerca i formació en antropologia, 25(2), 203-215. https://doi.org/10.5565/rev/periferia.799

Gibbs, H., \& Egermann, H. (2021). Music-evoked nostalgia and wellbeing during the United Kingdom Covid-19 pandemic: Content, subjective effects, and function. Frontiers in Psychology, 12. https://doi.org/ 10.3389/fpsyg.2021.647891

Giordano, F., Scarlata, E., Baroni, M., Gentile, E., Puntillo, F., Brienza, N., \& Gesualdo, L. (2020). Receptive music therapy to reduce stress and improve wellbeing in Italian clinical staff involved in Covid-19 pandemic: A preliminary study. Arts in Psychotherapy, 70. https://doi.org/10.1016/j.aip.2020.101688

Glaser, B. G., \& Strauss, A. L. (1967). The discovery of grounded theory: strategies for qualitative research. Aldine Transaction.

Global Citizen. (2020, April 19). Lady Gaga performs "Smile" I One world: Together at home [Video]. https://www.youtube.com/watch?v=cCNM706Iv8M $\& \mathrm{t}=1 \mathrm{~s}$

González-Sanguino, C., Ausín, B., Castellanos, M. Á., Saiz, J., López-Gómez, A., Ugidos, C., \& Muñoz, M. (2020). Mental health consequences during the initial stage of the 2020 coronavirus pandemic (Covid-19) in Spain. Brain, Behavior, and Immunity, 87, 172-176. https://doi.org/10.1016/j.bbi.2020.05.040

Granot, R., Spitz, D. H., Cherki, B. R., Loui, P., Timmers, R., Schaefer, R. S., Vuoskoski, J. K., CárdenasSoler, R.-N., Soares-Quadros, J. F., Jr., Li, S., Lega, C., La Rocca, S., Martínez, I. C., Tanco, M., Marchiano, M., Martínez-Castilla, P., Pérez-Acosta, G., MartínezEzquerro, J. D., Gutiérrez-Blasco, I. M., . . . Israel, S. (2021). "Help! I need somebody": Music as a global resource for obtaining wellbeing goals in times of crisis. Frontiers in Psychology, 12. https://doi.org/ 10.3389/fpsyg.2021.648013

Hall, S., \& Du Gay, P. (2003). Cuestiones de identidad cultural [Cultural identity issues]. Talleres Gráficos Color Efe.

Hansen, N. C. (2021). Music for hedonia and eudaimonia during pandemic social isolation. In T. Chemi, E. Brattico, L. O. Fjorback, \& L. Harmat (Eds.), The anthology: Arts and mindfulness education for human flourishing (pp. 1-13). Routledge.

Hansen, N. C., Treider, J. M. G., Swarbrick, D., Bamford, J. S., Wilson, J., \& Vuoskoski, J. K. (2021). A crowd-sourced database of coronamusic: Documenting online making and sharing of music during the COVID-19 pandemic. Frontiers in Psychology, 12. https://doi.org/10.3389/fpsyg.2021.684083

Ho, R. T., Fong, T. C., Sing, C. Y., Lee, P. H., Leung, A. B., Chung, K. S., \& Kwok, J. K. (2019). Managing behavioral and psychological symptoms in Chinese elderly with dementia via group-based music intervention: A cluster randomized controlled trial. Dementia, 18(7/8), 2785-2798. https://doi.org/ 10.1177/1471301218760023

IFEMA. (2020, April 21). Actuación de Sheila Blanco y Federico Lechner en el hospitallFEMA [Sheila Blanco and Federico Lechner performe at the IFEMA hospital] [Video]. https://www.youtube.com/watch?v= 18egLNJIyKM

Johnson, J. K., Stewart, A. L., Acree, M., Nápoles, A. M., Flatt, J. D., Max, W. B., \& Gregorich, S. E. (2020). A community choir intervention to promote wellbeing among diverse older adults: Results from the community of voices trial. The Journal of Geron- 
tology, Series B: Psychological Sciences and Social Sciences, 75(3), 549-559. https://doi.org/10.1093/ geronb/gby 132

Juanes y Alejandro Sanz en concierto en línea por Covid19 [Juanes and Alejandro Sanz in online concert due to Covid-19]. (2020, March 16). Milenio. https://www.milenio.com/espectaculos/famosos/ coronavirus-juanes-alejandro-sanz-concierto-lineacovid19

Keng, S. L., Tong, E. M., Yan, E. T. L., Ebstein, R. P., \& Lai, P. S. (2021). Effects of mindfulness-based stress reduction on affect dynamics: A randomized controlled trial. Mindfulness, 12(6), 1490-1501. https://doi.org/ 10.1007/s12671-021-01617-5

Krippendorff, K. (2004). Content analysis. An introduction to its methodology (2nd ed.). SAGE.

Kwok, S. Y. C. L. (2019). Integrating positive psychology and elements of music therapy to alleviate adolescent anxiety. Research on Social Work Practice, 29(6), 663-676. https://doi.org/10.1177/ 1049731518773423

Lindblad, K., \& de Boise, S. (2020). Musical engagement and subjective wellbeing amongst men in the third age. Nordic Journal of Music Therapy, 29(1), 20-38. https://doi.org/10.1080/08098131.2019.1646791

MacDonald, R., Burke, R., De Nora, T., Sappho Donohue, M., \& Birrell, R. (2021). Our virtual tribe: Sustaining and enhancing community via online music improvisation. Frontiers in Psychology, 11. https://doi.org/ 10.3389/fpsyg.2020.623640

Martín, J. C., Ortega-Sánchez, D., Miguel, I. N., \& Martín, G. M. G. (2021). Music as a factor associated with emotional self-regulation: A study on its relationship to age during Covid-19 lockdown in Spain. Heliyon, 7(2). https://doi.org/10.1016/j.heliyon.2021.e06274

Martínez-Castilla, P., Gutiérrez-Blasco, I. M., Spitz, D. H., \& Granot, R. (2021). The efficacy of music for emotional wellbeing during the Covid-19 lockdown in Spain: An analysis of personal and context-related variables. Frontiers in Psychology, 12. https://doi. org/10.3389/fpsyg.2021.647837

Mas-Herrero, E., Singer, N., Ferreri, L., McPhee, M., Zatorre, R., \& Ripolles, P. (2020). Rock ' $n$ ' roll but not sex or drugs: music is negatively correlated to depressive symptoms during the Covid-19 pandemic via reward-related mechanisms. PsyArXiv. https:// doi.org/10.31234/osf.io/x5upn

Ministerio de Cultura de Perú. (2020, April 16). “Contigo Perú" interpretado por integrantes del Coro Nacional y del Coro Nacional de Niños ["Contigo Perú" performed by the members of the National Choir and the National Children's Choir] [Video]. https://www. youtube.com/watch?v=PsSZcAj_NrQ

Montejano, Y., \& Rojas, G. (2020). Música maestro, escenarios virtuales en tiempos del covid-19 [Teachers' music, virtual scenarios in times of Covid-19]. Perifèria: Revista d'investigació i formació en Antropologia, 25(2), 154-166. https://doi.org/10.5565/rev/ periferia.729

Moss, H. (2019). Music therapy, spirituality and transcendence. Nordic Journal of Music Therapy, 28(3), 212-223. https://doi.org/10.1080/08098131. 2018.1533573

Mulemi, B. A. (2021). Lyrics and artistic improvisations in health promotion for the Covid-19 pandemic control in East Africa. Global Health Promotion, 28(1), 23-32. https://doi.org/10.1177/1757975920973671

Muñoz Pandiella, L. (2020, April 18). Un concierto para vencer al Covid-19-One world: Together at home [A concert to beat Covid-19-One world: Together at home]. France24. https://www.france24.com/es/ 20200418-covid19-concierto-one-world-togetherhome

Oriola, S., \& Gustems, J. (2015). Educación emocional y educación musical. Recursos didáctico-musicales para la consecución de competencias emocionales [Emotional education and music education. Didactic musical resources to achieve emotional competencies]. Eufonía: Didáctica de la música, 2015(64), 1-5. https://doi.org/10.13140/RG.2.1.5159.4968

Ozamiz-Etxebarria, N., Dosil-Santamaria, M., PicazaGorrochategui, M., \& Idoiaga-Mondragon, N. (2020). Niveles de estrés, ansiedad y depresión en la primera fase del brote del Covid-19 en una muestra recogida en el norte de España [Levels of stress, anxiety, and depression in the first phase of the Covid-19 outbreak in a sample collected in the north of Spain]. Cadernos de Saude Publica, 36(4), 1-10. https://doi. org/10.1590/0102-311X00054020

Partida Valdivia, J. M. (2020). Relación de sintonía mutua ante la contingencia sanitaria del Covid-19: Un breve análisis fenomenológico sobre la música [A tuned mutual relationship before Covid-19 health contingency: A brief phenomenological analysis of music]. Programa Universitario de Estudios sobre Democracia, Justicia y Sociedad.

Perea, A. (2020, March 16). \#SolidaritySession, la iniciativa de Chris Martin para sobrellevar la cuarentena [\#SolidaritySession, Chris Martin's initiative to cope with quarantine]. Quién. https://www.quien. com/espectaculos/2020/03/16/solidaritysessionla-iniciativa-de-chris-martin-para-sobrellevar-lacuarenta

Poulos, R. G., Marwood, S., Harkin, D., Opher, S., Clift, S., Cole, A. M., Rhee, J., Beilharz, K., \& Poulos, C. J. (2019). Arts on prescription for community-dwelling older people with a range of health and wellness needs. Health and Social Care in the Community, 27(2), 483-492. https://doi.org/10.1111/hsc.12669

Rimé, B. (2009). Emotion elicits the social sharing of emotion: Theory and empirical review. Emotion Review, 1(1), 60-85. https://doi.org/10.1177/ 1754073908097189

Stone, A. A., \& Mackie, C. (2013). Subjective well-being. Measuring happiness, suffering and other dimensions of experience. The National Academies Press. 
https://www.ncbi.nlm.nih.gov/books/NBK174473/ pdf/Bookshelf_NBK174473.pdf

Televisión Pública. (2020, March 27). Argentina canta "La cigarra" de María Elena Walsh [Argentina sings "La cigarra" by María Elena Walsh] [Video]. https://www. youtube.com/watch?v=HWhUTwy6qRc

Tull, M. T., Edmonds, K. A., Scamaldo, K. M., Richmond, J. R., Rose, J. P., \& Gratz, K. L. (2020). Psychological outcomes associated with stay-at-home orders and the perceived impact of Covid-19 on daily life. Psychiatry Research, 289. https://doi.org/10.1016/ j.psychres.2020.113098

Tunturuntu Cuba. (2020, March 30). Tunturuntu pa' tu casa sábado: 21 de marzo de 2020 [Tunturuntu to your home saturday: 21 March 2020] [Video]. https://www.youtube.com/watch?v=UeRWQpqFwmo

United Nations. (2017). Transforming our world: The 2030 agenda for sustainable development. In W. Rosa (Ed.), A new era in global health: Nursing and the United Nations 2030 agenda for sustainable development (pp. 529-567). Springer. https:// doi.org/10.1891/9780826190123.ap02

United Nations. (2020). La música no cura una pandemia, pero alegra el alma [Music does not cure a pandemic, but it cheers the soul]. https://www.un. org/es/coronavirus/articles/el-poder-de-la-musicadurante-coronavirus

Warner Music México. (2020, April 16) Resistiré México [I shall resist Mexico] [Video]. https://www.youtube. com/watch?v=uBGlv05JUJI

Yang, H., \& Ma, J. (2020). How an epidemic outbreak impacts happiness: Factors that worsen (vs. protect) emotional well-being during the coronavirus pandemic. Psychiatry Research, 289. https://doi.org/ 10.1016/j.psychres.2020.113045

Yang, H., \& Ma, J. (2021). Relationship between wealth and emotional well-being before, during, versus after a nationwide disease outbreak: A large-scale investigation of disparities in psychological vulnerability across Covid-19 pandemic phases in China. BMJ Open, 11(6), 1-8. https://doi.org/10.1136/bmjopen2020-044262

Zhao, J., Chen, C., \& Zhao, L. (2020). The spread characteristics of music videos relating to Covid-19 in China online video platforms. International Journal of Communication and Society, 2(1). https://doi.org/ 10.31763/ijcs.v2i1.94

\section{About the Author}

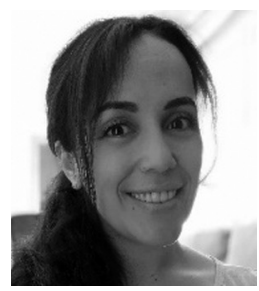

Priscila Alvarez-Cueva is a predoctoral researcher at the Communication Department of the Pompeu Fabra University in Barcelona, Spain. She earned her master's in international studies, media, power, and difference in 2018. Her research interests include gender studies, popular culture, and youth studies. She has finished a 3-month research visit at the University of Porto (2020) and has been invited as a visiting researcher at the University of Leuven (for 2022), School for Mass Communication Research. 